\title{
Psikoedukasi "IKESMEN" Untuk Meningkatkan Literasi Kesehatan Mental Siswa pada Guru
}

\author{
${ }^{1}$ Runi Rulanggi' $\mathcal{E}$ Thomas Dicky Hastjarjo ${ }^{2}$ \\ 1,2 Fakultas Psikologi Universitas Gadjah Mada
}

\begin{abstract}
This study was to determine the effects of "Ikesmen" (e-mental health) Psychoeducation program in improving mental health literacy in secondary school teachers in Yogyakarta. Thirty secondary school teachers in Yogyakarta participated in the study. Fifteen teachers in the experimental group received "Ikesmen" program and fifteen teachers in the control group did not receive treatment. The untreated control group design with pretest and posttest samples were used. The validity of "Ikesmen" program was tested in accordance to Rusell module development principles ( $\mathrm{V}$ coefficient is 0.775-0.8461). Literacy Questionnaires, Mental Health Stigma Questionnaires, and Mental health Knowledge Test were used to collect data. Mixed analysis of variance was conducted to analyse the data. The results showed that there were no differences in the scores of mental health literacy between the experimental group and control group $(\mathrm{F}=0.188, \mathrm{p}=0.01<0.668)$. There was no significant improvement in the experimental group treated with Ikesmen Psychoeducation in comparison with the control group $(\mathrm{F}=0.640, \mathrm{p}=0.01<0.431)$. Further research is required to obtain description on the impact of technology usage in improving mental health literacy.
\end{abstract}

Keywords: mental health literacy, psychoeducation, teachers

Abstrak. Penelitian ini bertujuan untuk mengetahui dampak "Ikesmen" dalam meningkatkan literasi kesehatan mental pada guru SMPN Yogyakarta. Penelitian ini dilakukan terhadap guru SMPN Yogyakarta $(\mathrm{N}=30)$ dengan metode eksperimen-kuasi. Desain penelitian menggunakan untreated control group design with pretest and posttest samples. Pengujian validitas menggunakan kaidah pengembangan modul Rusell (koefisien V sebesar 0,775-0,8461). Pengambilan data dengan menggunakan Kuisioner Literasi dan Stigma Kesehatan Mental serta tes pengetahuan kesehatan mental. Sampel penelitian ditentukan secara non-random dengan cara purposive sampling. Analisis data melalui anava (analisis varians). Hasil penelitian menunjukkan bahwa tidak ada perbedaan skor literasi kesehatan mental pada kelompok eksperimen atau pada kelompok kontrol $(F=0,188, p=0,01<0,668)$. Tidak ada peningkatan yang signifikan pada kelompok eksperimen yang diberikan Psikoedukasi Ikesmen dibandingkan dengan kelompok kontrol $(F=0,640, p=0,01<0,431)$.

Kata kunci : literasi kesehatan mental, guru, psikoedukasi

${ }^{1}$ Korespondensi mengenai isi artikel dapat dilakukan melalui: $\underline{\text { runi r@mail.ugm.ac.id, }}$

22Atau melalui dickyh@ugm.ac.id 
Permasalahan yang mengancam kesehatan jiwa remaja telah berkembang luas dan menjadi semakin kompleks. Hal ini dapat dilihat dari laporan WHO (2003) yang menyebutkan bahwa permasalahan yang terjadi pada remaja antara lain depresi, bunuh diri, gangguan psikotik, gangguan perkembangan pervasif, gangguan kelekatan, gangguan kecemasan, gangguan tingkah laku, penyalahgunaan zat, dan gangguan makan.

Kondisi ini juga dialami oleh remaja di Daerah Istimewa Yogyakarta (DIY). Fakta ini diperoleh dari hasil Riset Kesehatan Dasar (Riskesdas) Departemen Kesehatan Republik Indonesia (Depkes RI) tahun 2013. Hasil Riskesdas menunjukkan prevalensi kemunculan gangguan emosional sebesar $8,1 \%$ dari total penduduk Indonesia yang berusia $\geq 15$ tahun (Departemen Kesehatan RI, 2015). Kekerasan, tawuran, bullying dan penyalahgunaan zat-zat berbahaya oleh remaja, dan klitih, atau kekerasan yang dilakukan oleh sekelompok orang di jalanan belakangan menjadi sorotan di Yogyakarta.

Masalah-masalah ini mengancam kehidupan kehidupan remaja berusia sekolah. Akan tetapi, sekolah belum mampu memberikan perhatian yang cukup terhadap masalah siswa (Kumara, 2011). Kondisi ini terjadi karena komponen sekolah belum memahami masalah siswa. Oleh karena itu, dibutuhkan upaya untuk meningkatkan pengetahuan pada komponen sekolah. Hal ini berdasarkan pendapat Harry Minas, peneliti dari University of Melbourne pada School Well-being and Children Mental Health Workshop (9/2/2015) yang menyebutkan bahwa pendidikan untuk guru diperlukan untuk meningkatkan kualitas kesehatan jiwa siswa (ugm.ac.id, 2016).

Sekolah berperan terhadap upaya peningkatan kualitas kesehatan mental siswa (Kutcher, Venn \& Szumilas dalam Froese-Germain, Riel \& Canadian Teachers Federation, 2012). Upaya ini dapat dilakukan jika sekolah dapat mencegah dan menanggulangi masalah yang mengancam kehidupan siswa (Christner \& Mennuti, 2009). Hal ini dapat terwujud melalui dukungan dari personil sekolah, siswa dan orangtua (Kramer, Vuppala, Lamps, Miller \& Trush, 2006). Komponen yang berperan penting adalah guru. Loades \& Mastroyannopoulou (2010) mengungkapkan bahwa guru berperan penting untuk mengawasi gangguan emosi dan perilaku pada anak dan remaja serta memberikan treatment pada siswa yang memiliki masalah psikologis. Guru ibarat penyedia layanan kesehatan mental yang memberikan penilaian dan pengobatan bagi klien (Kramer, et al., 2006).

Pengetahuan guru mengenai masalah siswa merupakan hal yang penting untuk dimiliki oleh guru sebab hal ini terbukti dapat mengatasi masalah siswa, seperti bullying (Whitley, Smith, \& Vaillancourt, 2012). Guru yang memiliki pengetahuan tentang bullying dapat menyampaikan informasi ini pada siswa. Siswa menjadi lebih percaya diri untuk menceritakan permasalahan pada guru sehingga akan memunculkan inisiatif pada siswa untuk mendapatkan penanganan profesional sehingga dapat meningkatkan peluang keberhasilan proses treatment (Langeveld, Joa, Larsen, Rennan, Cosmovici, \& Johannessen, 2011). Keterlibatan guru sebagai komponen sekolah menjadi penting 
untuk meningkatkan kualitas kesehatan mental siswa, terutama pada masa transisi sekolah, seperti dari masa sekolah dasar menuju sekolah menengah pertama (Vaz, Falkmer, Parsons, Passmore, Parkin, \& Falkmer, 2014).

Pengetahuan guru mengenai kesehatan mental merupakan langkah awal untuk mengatasi masalah pada siswa atau dikenal dengan istilah literasi kesehatan mental. Literasi kesehatan mental merupakan pengetahuan dan keyakinan tentang gangguan mental (Jorm, 2011). Pengetahuan tentang kesehatan mental ini seharusnya dimiliki oleh masing-masing individu, termasuk guru.

Peningkatan pengetahuan guru dapat dilakukan melalui intervensi psikologi. Bentuk intervensi psikologi pada guru dapat dilakukan dengan psikoedukasi secara universal. Bentuk intervensi universal lebih tepat diterapkan pada penelitian ini sebab intervensi universal bertujuan untuk membangun faktor protektif untuk menurunkan kerentanan penyakit pada individu. Hal ini juga dilakukan sebagai upaya penerapan koping untuk mencegah munculnya permasalahan serta menawarkan sumber daya global yang dibutuhkan pada individu yang berisiko mengalami masalah. Intervensi ini dibutuhkan untuk memberi alternatif koping dan sumber daya yang dibutuhkan siswa untuk menghadapi masalah yang mengancam kesehatan mental. Bentuk intervensi universal merupakan bagian dari promosi dan pencegahan masalah mental (Christner \& Mennuti, 2009).

Perkembangan teknologi yang pesat memberi kesempatan pengembangan layanan kesehatan mental berbasis teknologi. Seiring dengan perkembangan teknologi informasi, psikoedukasi dapat dilakukan dengan bantuan smartphone melalui aplikasi. Luxton, Russell, Bush, Mishkind \& Reger (2011) menyebutkan bahwa layanan psikoedukasi berbentuk aplikasi kesehatan mental telah semakin banyak ditemui (Jones \& Ashurst, 2013). Layanan ini disebut e-mental health (Christensen \& Petrie, 2012) atau belakangan ini lebih dikenal dengan istilah mHealth (mobile health) (Bull \& Ezeanochi, 2016). mHealth didefinisikan sebagai bentuk promosi kesehatan dan program penanggulangan penyakit melalui pesan singkat (SMS), media sosial dan aplikasi pada handphone atau tablet. Bentuk layanan ini dapat diakses oleh individu secara luas. Layanan ini memiliki progam untuk mengubah perilaku serta memfasilitasi perawatan pada individu yang mengalami masalah (Bull \& Ezeanochi, 2016).

Mhealth juga telah menjangkau sektor pendidikan. East (2015) menunjukkan $m$ Health dapat digunakan oleh konselor pendidikan sebagai sarana psikoedukasi kesehatan mental siswa. Penggunaan aplikasi kesehatan mental ini perlu diberikan pada semua komponen sekolah termasuk guru, sebab teknologi merupakan bagian tak terpisahkan dari kehidupan individu masa kini (Keren-Kolb, 2010).

Pengembangan aplikasi membutuhkan desain instruksional diperlukan sebagai pedoman untuk memfasilitasi materi (Reigeluth \& Charr-Chellman, 2009). Russell \& Johanningsmeier (1981) menyebutkan bahwa langkah-langkah penyusunan instruksi meliputi penentuan tujuan, penyusunan tes pengetahuan, analisis karakteristik dan spesifikasi perilaku yang dituju, penyusunan desain, uji coba desain serta evaluasi desain. 
Psikoedukasi yang diberikan pada guru melalui Aplikasi (selanjutnya disebut Ikesmen) ini diharapkan dapat membantu guru memahami masalah siswa sehingga guru memiliki kemampuan literasi kesehatan mental yang tinggi. Hal ini bertujuan untuk meningkatkan kualitas kesehatan mental siswa. Kesehatan Mental merupakan kondisi well-being dimana setiap individu menyadari potensi yang dimilikinya, dapat mengatasi tekanan hidup yang normal, dapat bekerja secara produktif dan berkontribusi pada masyarakat (WHO, 2003).

\section{Metode}

Subjek penelitian dalam penelitian ini adalah guru laki-laki dan perempuan di SMPN "A", SMPN "B" dan SMPN "C" Yogyakarta sejumlah 30 orang. Guru yang dijadikan sebagai subjek penelitian memiliki kriteria sebagai berikut : merupakan guru Sekolah Menengah Pertama Negeri di Yogyakarta yang terakreditasi "A"; tingkat pendidikan setidaknya Diploma ; belum pernah mendapatkan pendidikan atau pelatihan khusus terkait dengan kesehatan mental siswa di sekolah serta bersedia mengikuti kegiatan penelitian berupa Ikesmen. Instrumen yang digunakan pada penelitian ini adalah pertama, Kuisioner Literasi dan Stigma Kesehatan Mental yang diadaptasi dari Mental Health Literacy and Stigma Questionnaire yang disusun oleh Reavley \& Jorm (2011) yang terdiri dari 13 aitem pertanyaan. Kedua, cek Manipulasi dengan Tes Pengetahuan Kesehatan Mental Siswa yang disusun oleh peneliti dan terdiri 14 aitem yang berkaitan dengan aspek Psikoedukasi Ikesmen. Ketiga, Modul Psikoedukasi Ikesmen yang disusun oleh peneliti. Modul bertujuan untuk mempromosikan kesehatan dan memperkenalkan kesehatan mental siswa pada guru. Keempat, Lembar observasi peserta. Observasi dilakukan dengan dengan menggunakan metode observasi partisipan. Kelima, Lembar Evaluasi Media untuk menilai sejauhmana media Aplikasi Ikesmen dapat dipahami dan diakses oleh individu.

Penelitian dilakukan dengan menggunakan desain eksperimenkuasi. Eksperimenkuasi merupakan penentuan kelompok secara tidak acak (Shadish, Cook \& Campbell, 2002). Eksperimen-kuasi merupakan penelitian yang bertujuan untuk menguji hipotesis penyebab terhadap manipulasi yang mengakibatkan suatu akibat tertentu. Akan tetapi, pada eksperimen kuasi tidak dilakukan random assignment pada kelompok kontrol dan kelompok eksperimen.

Penelitian yang akan dilakukan ini hendak menggunakan desain untreated control group design with dependent pretest and posttest samples. Hal ini dilakukan sebab desain ini merupakan desain yang paling banyak digunakan dalam eksperimen-kuasi (Shadish, Cook \& Campbell, 2002).

Psikoedukasi "Ikesmen" adalah suatu bentuk pendidikan pribadi dan sosial yang bertujuan untuk mempelajari aneka life skills untuk mencegah munculnya masalah mentalmelalui suatu program terstruktur pada kelompok, komunitas atau masyarakat yang dilakukan dengan menggunakan bantuan teknologi komunikasi seperti smartphone dan tablet. Bentuk psikoedukasi ini bertujuan untuk mempromosikan kesehatan mental pada masyarakat. Layanan psikoedukasi dengan mobile health berbentuk aplikasi kesehatan mental untuk menghadapi masalah mental. Aplikasi 
kesehatan mental ini (selanjutnya dinamakan "Ikesmen") terdiri dari 3 aspek, yakni: mengidentifikasi dan memahami masalah siswa, mendengarkan tanpa memihak, dan mendorong siswa untuk mendapatkan layanan kesehatan mental. Masing-masing aspek dijelaskan sebagai berikut.

Pertama, mengidentifikasi dan memahami masalah siswa. Hal ini terkait dengan kemampuan guru untuk mengenali masalah mental pada siswa, termasuk melakukan deteksi awal terhadap masalah siswa. Kedua, mendengarkan tanpa memihak. Hal yang penting dilakukan dalam proses mendengarkan adalah tidak memberi penilaian terlebih dahulu atas kondisi yang dialami oleh siswa. Ketiga, mendorong siswa untuk mendapatkan layanan kesehatan mental. Dorongan yang dimaksud yakni menyediakan lingkungan yang dapat membantu siswa untuk mengurangi tekanan-tekanan yang dapat memperbesar risiko munculnya masalah mental (terutama di sekolah) serta bagaimana guru menghadapi seorang siswa yang menunjukkan masalah mental.

Psikoedukasi Ikesmen merupakan aplikasi yang terinstal pada smartphone berbasis android. Adapun spesifikasi smartphone yang dapat digunakan untuk mendapatkan informasi mengenai kesehatan mental siswa dari Aplikasi Ikesmen adalah : Smartphone yang memiliki sistem operasi Android Minimal 4.1.1 (Jellybean), minimal RAM 512 MB, dan perangkat terkoneksi dengan internet.

\section{Pembahasan}

Hasil penghitungan rata-rata pretest pengetahuan pada kelompok eksperimen lebih rendah $(\mathrm{M}=10,67, \quad \mathrm{SD}=2,093)$ dibandingkan dengan kelompok kontrol $(\mathrm{M}=11,73, \mathrm{SD}=1,438)$. Akan tetapi pada saat posttest rata-rata pengetahuan kelompok eksperimen lebih tinggi $(\mathrm{M}=11,93, \mathrm{SD}=1,534)$ dibandingkan dengan kelompok kontrol $(\mathrm{M}=11,13, \quad \mathrm{SD}=1,552)$. Pada kelompok eksperimen, terjadi peningkatan skor pengetahuan kesehatan mental rata-rata sebesar 1,26 poin. Sedangkan pada kelompok kontrol, terjadi penurunan skor pengetahuan kesehatan mental siswa sebesar rata-rata 0,6 poin.

Skor pretest literasi kesehatan mental siswa oleh guru menunjukkan bahwa pada kelompok eksperimen rata-rata pretest lebih tinggi dibandingkan dengan kelompok kontrol sebesar 8,40. Adapun pada kelompok kontrol, skor pretest lebih rendah yakni sebesar 7,53. Pada posttest skor literasi kesehatan mental lebih tinggi pada kelompok eksperimen tetap lebih tinggi dibandingkan dengan kelompok eksperimen yakni sebesar 8,20 dibandingkan dengan kelompok kontrol sebesar 8,07. Akan tetapi, terdapat penurunan skor literasi kesehatan mental siswa pada kelompok eksperimen sebesar 0,2 poin dan kenaikan pada kelompok kontrol sebesar 0,53 poin.

Hasil analisis dengan anakova menunjukkan tidak adanya interaksi antara terdapat interaksi antara time (pre-post-test) dan masing-masing kelompok (eksperimenkontrol) $(\mathrm{F}=0,188, \mathrm{p}=0,668>0,01)$. Hasil analisis untuk melihat perbedaan pada kelompok eksperimen dibandingkan dengan kelompok kontrol menunjukkan bahwa tidak ada perbedaan literasi kesehatan mental pada kelompok eksperimen dibandingkan dengan kelompok kontrol $(F=0,640, p=F=0,640, p=$ 
$0,01<0,431)$. Konten dari aplikasi Ikesmen dapat dilihat pada gambar 1 .
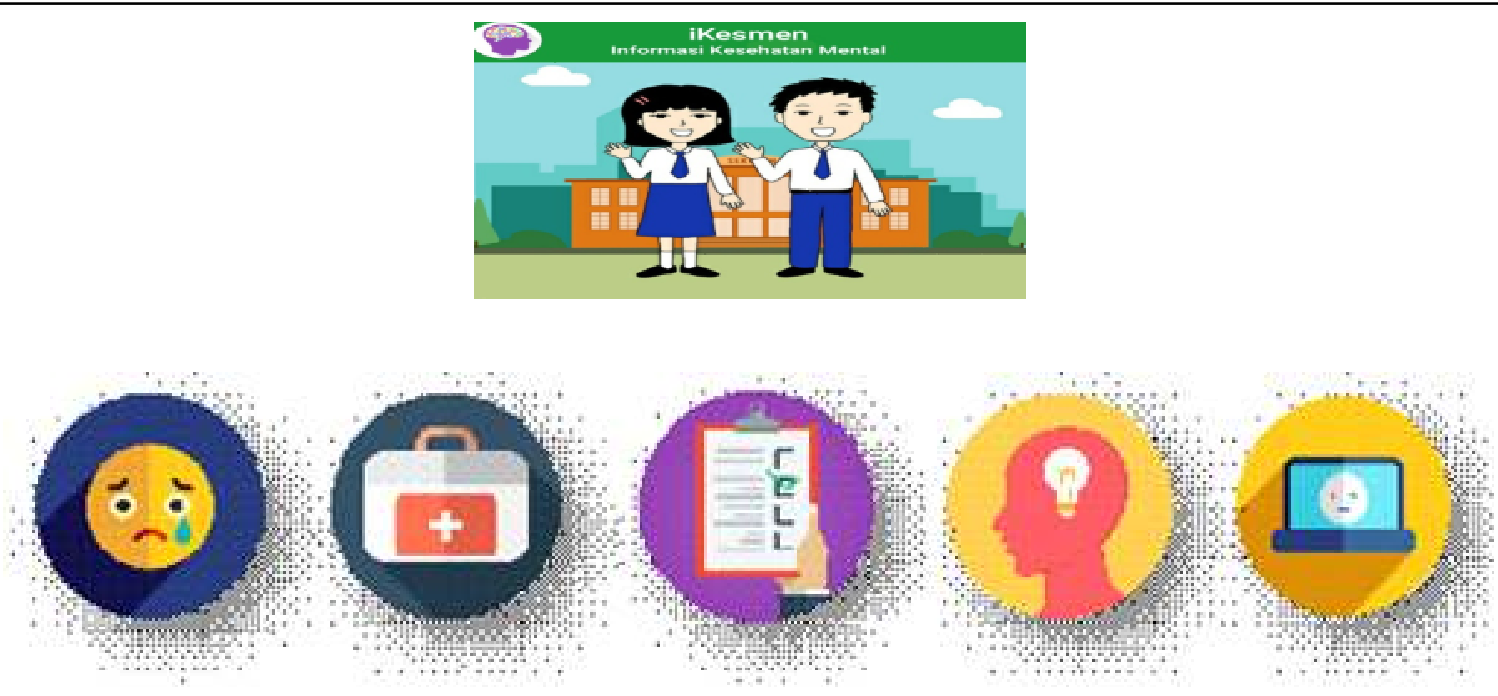

Cejale: bers: informas mengenat knia, baraketrisk dampak kerentanan din strateg pertolongan mandin bag sava yang meng alams gavggan

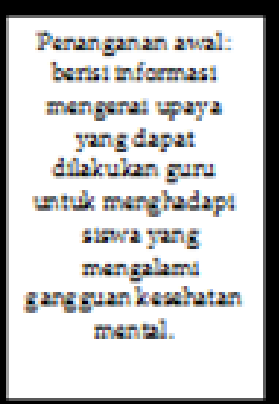

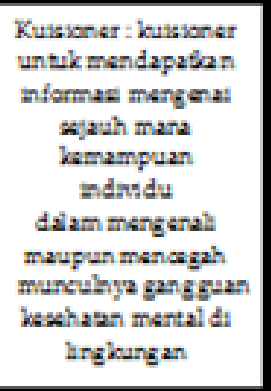

Kuis : berisi tes untuk menguf pengetahuan individu mengenai keshack mental siswa

\section{Link tekikan:}

Beris

informas:

mengena:

penyedis

layzan

keskiatan

mertal

srdekat yeng

dapat dirujuk

Gambar 1.

Tampilan awal dan Konten dari aplikasi Ikesmen

Tabel 1

Statistik Deskriptif Literasi Kesehatan Mental Guru

\begin{tabular}{lllllllll}
\hline Kelompok & Pretest & & \multicolumn{4}{c}{ Posttest } \\
& $\mathrm{N}$ & Rata-rata & SD & Varians & N & Rata-rata & SD & Varians \\
\hline Eksperimen & 15 & 8,40 & 2,69 & 7,257 & 15 & 8,20 & 3,02 & 9,171 \\
& & & 4 & & & & 8 \\
Kontrol & 15 & 7,53 & 1,95 & 3,838 & 15 & 8,07 & 2,28 & 5,210 \\
& & & 9 & & & & 2 \\
\hline
\end{tabular}


Tabel 2.

Analisis Varians Literasi Kesehatan Mental pada Guru

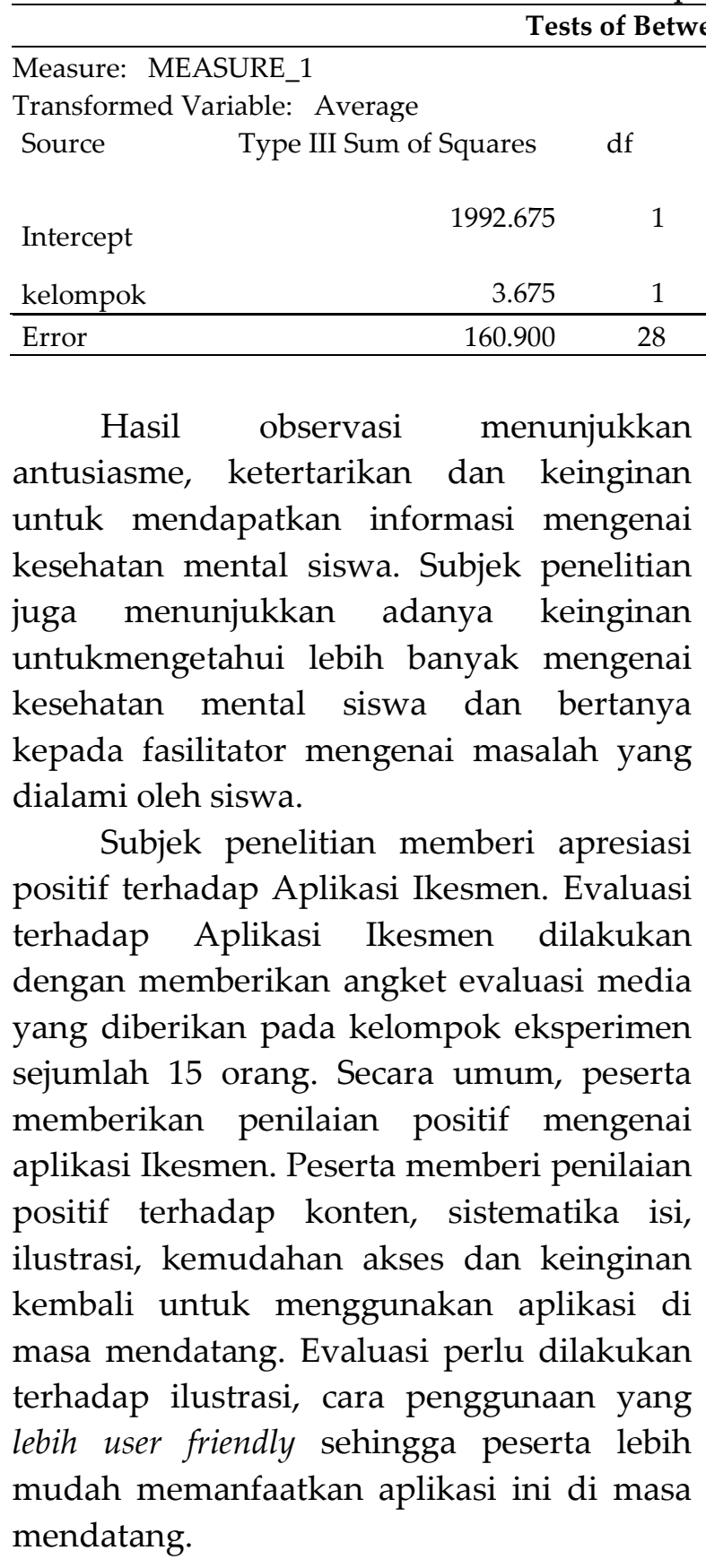

\section{Diskusi}

Literasi kesehatan mental adalah pengetahuan dan keyakinan individu terkait pemahaman mengenai gangguan mental.
Kemampuan ini dapat membantu individu untuk mengenali, mengelola dan mencegah masalah mental baik pada diri sendiri maupun orang lain (Jorm, 2011). Literasi kesehatan mental (Reavley \& Jorm, 2011) terbagi dalam 9 aspek sebagai berikut.

Pertama, pemahaman terkait definisi gangguan mental. Hal ini mencakup pemahaman terhadapi masalah mental seperti depresi, tindakan untuk bunuh diri, gejala skizofrenia, gangguan skizofrenia akut, fobia sosial dan gangguan stres pasca trauma. Kedua, mengenali gangguan dan keyakinan terhadap penanganan gangguan. Hal ini mencakup pandangan terhadap individu yang mengalami gangguan mental, bagaimana individu dapat memberikan bantuan kepada penyandang gangguan mental, bagaimana pandangan individu terkait bentuk bantuan yang tersedia untuk membantu penyandang gangguan mental dalam menghadapi masalah. Ketiga, kecenderungan dan keyakinan diri untuk memberikan perotolongan pertama pada

penyandang gangguan mental. Hal ini mencakup bagaimana kesediaan individu untuk membantu seseorang yang menyandang gangguan mental jika orang tersebut memiliki relasi dekat dengan individu, tindakan yang akan dilakukan individu untuk membantu orang yang memiliki hubungan dekat dengan diri untuk mengatasi masalah mental, serta bentuk 
dukungan yang akan diberikan untuk membantu individu yang mengalami masalah mental. Keempat, keyakinan terhadap peluang kesembuhan individu. Hal ini mencakup bagaimana keyakinan individu dalam memadang penyandang gangguan mental untuk lepas dari masalah yang dihadapi, serta seperti apa individu kemungkinan individu untuk menjalani kehidupan yang lebih baik setelah terpapar masalah mental. Kelima, keyakinan terhadap penyebab dan faktor resiko gangguan. Hal ini mencakup serangkaian pilihan mengenai faktor apa saja yang dapat memicu kemungkinan terjadinya gangguan mental pada individu serta seberapa yakin individu meyakini sebuah faktor dapat menjadi penyebab munculnya gangguan mental tertentu. Keenam, paparan gangguan mental (dalam lingkungan terdekat). Hal ini mencakup bagaimana reaksi individu individu ketika menghadapi keluarga atau relasi terdekat mengalami gangguan mental tertentu serta bentuk bantuan seperti apa yang akan diberikan oleh individu terhadap relasi atau keluarga tersebut. Ketujuh, sikap individu terkait stigma mengenai gangguan mental, yang mencakuo stigma pribadi terkait individu gangguan mental, jarak sosial serta diskriminasi yang diterima individu yang mengalami gangguan mental. Kedelapan, Penanganan terhadap masalah mental. Hal ini mencakup bagaimana bentuk penanganan terhadap masalah mental yang diterima individu selama ini (jika pernah mendapatkan penanganan). Kesembilan, mengetahui kemampuan individu dalam mengenali keterlibatan organisasi penyeedia layanan kesehatan mental. Hal ini mencakup pengetahuan individu mengenai organisasi yang menyediakan layanan kesehatan mental yang tersedia di masyarakat.

Rendahnya literasi kesehatan mental merupakan masalah yang dihadapi oleh negara-negara di Asia, termasuk di Indonesia. Akan tetapi di sisi lain teknologi dan infrastruktur berkembang pesat di Asia. Populasi Asia tercatat merupakan separuh dari pasar teknologi mobile di dunia. Hal ini memberi peluang bagi pengembangan layanan kesehatan mental berbasis teknologi. Akan tetapi, penyediaan layanan kesehatan di Asia, termasuk Indonesia sebaiknya memerhatikan norma-norma budaya setempat (Arandjelovic, Eyre, Forbes, Bauer, Aggarwal, Singh, Baune, Everall, Berk, dan Ng, 2016).

Penelitian mengenai literasi kesehatan mental yang dilakukan di negara berkembang menunjukkan bahwa pemahaman mengenai kesehatan mental secara umum masih minim. Minimnya pemahamanan ini membuat perlunya upaya peningkatan literasi kesehatan pada masyarakat, termasuk pada penyedia layanan kesehatan mental. Akan tetapi, peningkatan literasi ini harus dilakukan secara komprehensif (Ganasen, Parker, Hugo, Stein, Emaley \& Soedat, 2008). Upaya pemberian psikoedukasi sebaiknya diberikan secara menyeluruh, tidak hanya pada guru. Hal ini dikarenakan komponen sekolah tidak hanya terdiri dari guru, tapi juga terdiri dari karyawan, kepala sekolah, orangtua dan siswa sehingga diperlukan usaha yang terpadu dari masing-masing komponen ini untuk mewujudkan kualitas kesehatan mental siswa yang lebih baik.

Psikoedukasi Ikesmen disusun berdasarkan kaidah pendekatan kognitif untuk meningkatkan literasi kesehatan mental. Pendekatan kognitif menekankan 
bahwa proses belajar yang berpusat pada pembelajar (Reigeluth \& Charr-Chellman, 2009). Salah satu bagian dari pendekatan kognitif adalah pendekatan pemrosesan informasi yang memandang pikiran sebagai prosesor yang menghimpun informasi. Fokus dari pendekatan pemrosesan informasi adalah pemaknaan informasi yang diterima individu. Proses membuat sebuah hal menjadi bermakna dilakukan melalui tahapan instruksi. Tahapan instruksi ini dapat dirancang sedemikian rupa untuk mendapatkan perubahan psikologis pada individu. Pada penelitian ini, desain instruksi dirancang untuk memberi perubahan berupa meningkatkan kemampuan individu dalam mengenali, mengelola dan mencegah masalah mental pada siswa atau yang sebelumnya dijelaskan sebagai literasi kesehatan mental. Desain instruksi ini telah umum digunakan dalam bidang pendidikan (Harasim, 2012). Desain instruksi yang digunakan dalam peneltian ini berupa modul psikoedukasi. Adapun untuk menjadikan sebuah modul dapat memberi peningkatan literasi kesehatan mental, dilakukan proses validasi berdasarkan kaidah pengembangan modul Rusell \& Johanningsmeier (1981). Russell \& Johanningsmeier (1981) menyebutkan langkah-langkah pengembangan modul meliputi penentuan tujuan, penyusunan tes pengetahuan, analisis karakteristik dan spesifikasi perilaku yang dituju, penyusunan desain, uji coba desain serta evaluasi modul.

Penelitian ini memberikan informasi mengenai literasi kesehatan mental di Kota Yogyakarta. Hasil penelitian ini membuktikan bahwa meskipun tidak ada peningkatan yang signifikan pada literasi kesehatan mental pada guru di SMPN
Yogyakarta tidak signifikan. Hasil analisis dengan analisis varians menunjukkan tidak adanya interaksi yang signifikan antara Psikoedukasi Ikesmen dengan peningkatan literasi kesehatan mental pada kelompok eksperimen $(F=0,601, p=0,445>0,01)$.

Akan tetapi, bentuk media ini memberi peluang bagi pengembangan layanan kesehatan mental sekolah di masa depan. Hal ini didukung oleh respon peserta yang antusias terhadap bentuk layanan psikoedukasi ini dan pandangan peserta yang menginginkan adanya pengembangan layanan psikoedukasi dengan aplikasi android di masa depan. Psikoedukasi ini memberi gambaran bahwa dibutuhkan kesiapan dari komponen sekolah, seperti karyawan, kepala sekolah, orangtua dan siswa.

Penelitian-penelitian mengenai pemberian layanan kesehatan mental berbasis teknologi menunjukkan bahwa efektivitas pemberian layanan dengan aplikasi memiliki efektivitas yang beragam. Penelitian yang dilakukan oleh Anshari \& Almunawar (2016) menunjukkan bahwa layanan mobile health memiliki tantangan dalam penerapannya, seperti terkait reliabilitas layanan kesehatan mental berbasis teknologi. Hal ini dapat ditanggulangi dengan memperhatikan alat yang digunakan, memastikan kualitas dari penyedia layanan kesehatan mental yang dirujuk dan terjaminnya informasi yang didapatkan dari layanan mobile health.

Hasil penelitian ini menunjukkan bahwa Psikoedukasi dengan menggunakan Aplikasi Ikesmen memiliki keterbatasan sehingga mengancam validitas internal eksperimen. Ancaman terhadap validititas internal. Ancaman terhdap validitas internal seperti yang dikemukakan oleh Hastjartjo 
(2011) terdiri dari beberapa hal, diantaranya sebagai berikut. Pertama, seleksi. Pada penelitian seleksi dapat terjadi tanpa disadari oleh peneliti. Perbedaan karakteristik guru SMPN B dan C yang dijadikan sebagai subjek eksperimen dengan karakteristik guru SMPN A yang dijadikan sebagai kelompok kontrol dapat memengaruhi hasil penelitian yang berpengaruh terhadap inferensi. Seperti perbedaan pengetahuan guru mengenai masalah siswa dan pengalaman mengajar atau berinteraksi dengan siswa yang berbeda-beda. Kedua, Maturasi. Perubahan alami yang terjadi di antara jeda waktu pretest dan posttest, misalnya faktor belajar subjek terhadap alat ukur penelitian pada kelompok kontrol dapat menimbulkan efek yang dapat diduga sebagai efek perlakuan psikoedukasi.

Faktor-faktor yang dapat memengaruhi literasi kesehatan mental diantaranya yakni kelamin (Loades \& Mastroyannopoulou, 2010), pengalaman guru dalam menghadapi masalah mental tertentu (Loades \& Mastroyannopoulou, 2010) dan keyakinan dan pengalaman mengajar guru (Murray \& Pianta, 2007). Akan tetapi, temuan yang didapatkan pada penelitian ini menunjukkan hasil sebaliknya. Jenis kelamin, serta pengalaman mengajar tidak memengaruhi literasi kesehatan mental dalam penelitian ini. Hah ini berkebalikan dengan beberapa penelitian yang menguji peran dari pengalaman mengajar terhadap pengetahuan mengenai kesehatan mental siswa. Hal ini dapat disebabkan oleh perbedaan karakteristik subjek penelitian.

Pemberian layanan kesehatan mental di masa depan aksan bertransfomasi menggunakan bantuan teknologi. Hal ini didukung oleh pendapat Christensen \& Petrie (2012) yang menyebutkan bahwa layanan kesehatan mental akan bertransformasi ke arah yang lebih canggih dengan menggunakan teknologi sebagai alat bantu. Akan tetapi, diperlukan kesiapan dari penyedia layanan kesehatan mental untuk meningkatkan kualitas layanan berbasis teknologi. Layanan kesehatan mental berbasis teknologi seperti layanan mobile health dapat dijadikan sebagai media promosi kesehatan mental dan program selfmanagement yang bermanfaat untuk menjelaskan pentingnya kesehatan mental pada individu.

Adapun tantangan yang dihadapi adalah keterbatasan penelitian yang ada selama ini berkaitan dengan efektivitas penggunaan layanan mobile health pada individu (Bull \& Ezeanochie, 2016). Hal ini tampaknya juga menjadi tantangan bagi penyedia layanan kesehatan mental di Indonesia sebab ketersediaan akses informasi dan teknologi belum merata di Indonesia. Hal ini sesuai dengan hasil temuan Anshari \& Almunawar (2016) yang menyebutkan bahwa tantangan yang dihadapi oleh Indonesia dalam mengembangkan layanan mobile health berbasis teknologi adalah ketersediaan alat yang digunakan sebagai sarana mobile health, kualitas penyedia layanan kesehatan mental yang ada dan kualitas informasi yang diberikan pada masyarakat.

Hasil penelitian ini menguatkan pendapat yang disebutkan oleh Anshari \& Almunawar (2016) bahwa perangkat mobile health yang digunakan untuk memberi informasi mengenai kesehatan mental yang ada masih membutuhkan pengembangan sehingga belum dapat berfungsi secara optimal sebagai penyedia informasi 
kesehatan mental. Selain itu, belum adanya sistem yang terpadu antara penyedia layanan kesehatan mental (primer, sekunder, terseier) dan pemberi informasi kesehatan mental. Akibatnya pengguna layanan masih menjadikan informasi yang didapatkan melalui aplikasi sebagai tambahan informasi dan bukan menjadi sumber utama untuk mendapatkan informasi mengenai kesehatan mental.

Berdasarkan pemaparan-pemaparan sebelumnya mengenai dinamika pengembangan layanan mobile health di Inonesia dapat disimpulkan bahwa layanan mobile health berupa Aplikasi android dapat dijadikan sebagai salah satu alternatif solusi untuk memperluas layanan kesehatan mental yang sudah ada. Akan tetapi, dibutuhkan kerjasama yang terpadu antara penyedia layanan kesehatan mental yang ada dan pengembangan infrastruktur berupa perangkat teknologi yang memadai untuk mengembangkan layanan kesehatan mental berbasis teknologi yang dapat dimanfaatkan secara luas. Upaya tersebut dapat diterapkan pada komponen sekolah, baik pada guru, kepala sekolah, karyawan, orangtua dan siswa. Hasil penelitian ini menunjukkan bahwa masih terbuka peluang yang sangat besar untuk mengembangkan sistem layanan kesehatan mental berbasis sekolah yang integratif, melibatkan komponen sekolah, pemangku kebijakan, dan komunitas (seperti penyedia layanan kesehatan mental dan masyarakat) untuk membantu mewujudkan cita-cita kualitas kesehatan mental siswa Yogyakarta yang lebih baik.

\section{Kesimpulan}

Hasil penelitian menunjukkan bahwa tidak ada perbedaan skor literasi kesehatan mental pada kelompok eksperimen atau pada kelompok kontrol $(\mathrm{F}=0,188, \mathrm{p}=0,01<$ 0,668). Hasil penelitian ini juga menunjukkan tidak ada peningkatan yang signifikan Psikoedukasi Ikesmen terhadap literasi kesehatan mental guru SMPN Yogyakarta $(\mathrm{F}=\mathrm{F}=0,601, \mathrm{p}=0,445>0,01)$.

\section{Saran}

Hasil ini menunjukkan perlu dilakukan evaluasi terhadap bentuk layanan Psikoedukasi Ikesmen ini baik terhadap peneliti selanjutnya, praktisi pendidikan dan pemangku kebijakan terkait. Bagi penelitian selanjutnya, diharapkan pengembangan aplikasi Ikesmen ini di masa depan dengan memperhatikan karakteristik subjek seperti usia, jenis kelamin, tingkat pendidikan dan status pernikahan subjek penelitian. Diperlukan pengembangan aplikasi Ikesmen yang lebih baik, termasuk perlunya peningkatan validitas alat dan keterpercayaan informasi yang terdapat pada aplikasi Ikesmen. Penelitian ini dapat membuka jalan bagi penelitian-penelitian selanjutnya di bidang kesehatan mental yang memanfaatkan teknologi sebagai media intervensi. Penelitian ini membuka jalan bagi pengembangan konten dan layanan kesehatan mental (baik primer, sekunder dan tersier) di Yogyakarta yang dapat berafiliasi dengan sistem sekolah.

Selain itu diperlukan usaha peningkatan kualitas materi Psikoedukasi untuk mencapai tujuan bagi peningkatan literasi kesehatan mental.

Bagi praktisi pendidikan, aplikasi Ikesmen ini dapat dijadikan sebagai cara untuk meningkatkan layanan kesehatan mental siswa di sekolah yang selama ini belum banyak diberikan pada siswa dengan meningkatkan kualiitas konten. Bagi 
pemangku kebijakan, bentuk layanan kesehatan mental melalui aplikasi android dapat dipertimbangkan sebagai salah satu metode baru untuk memberikan layanan kesehatan mental di sekolah. Upaya ini dapat terwujud dengan syarat peningkatan kualitas aplikasi ini di masa mendatang.

\section{Kepustakaan}

Anshari, M., \& Almunawar, M.A. (2016). Mobile Health (mHealth) Services and Online Health Educators. Biomedical Informatics Insights. 8, 1927.doi: $10.4137 /$ Bii .s35388.

Bull, S., \& Ezeanochi, N. (2016). From foucault to freire through facebook: toward an integrated theory of mhealth, Health Education $\mathcal{E}$ Behavior, 43, 4 399-411. doi: 10.1177/1090198115605310.

Christner, R.W., \& Mennuti, R. B. (2009). School-Based Mental Health. New York : Routledge.

Christensen, H., \& Petrie, K. (2012). Information technology as the key to accelerating advances in mental health care, Australian \& New Zealand Journal of Psychiatry, 47, 2, 114-116. doi: 10.1177/0004867412471088.

Departemen Kesehatan RI. (2015, Oktober). Hasil Riset Kesehatan DIY Tahun 2013. DIterima dari: www.depkes.go.id.

East, M. L. (2015). Mental Health Mobile Applications In Counselor Education. (Disertasi, The University of West Florida). Diterima dari: http://search.proquest.com.

Froese-Germain,B. Riel., R. \& Canadian Teachers Federation. (2012). Understanding Teachers' Perspectives on Student Mental Health: Findings
From a National Survey. Diterima dari Canadian Teachers Federation. Diterima dari: www.ctf-fce.ca.

Hastjartjo, T.D. (2011, Desember). Validitas Eksperimen. Buletin Psikologi,19, 2. Diterima dari : http://dickyh.staff.ugm.ac.id.

Harasim, L. (2012). Learning Theory and Online Technologies. Diterima dari: http://wladimirbarozzo.files.wordpre ss.com.

Jones, R. B., \& Ashurst, E. J. (2013). Online anonymous discussion between service users and health professionals to ascertain stakeholder concerns in using ehealth services in mental health, Health Informatics Journal, 19, 4, 281299. doi: $10.1177 / 1460458212474908$.

Jorm, A.F.(2011). Mental Health Literacy: Empowering the Community to Take Action for Better Mental Health. American Psychologist, 67, 3, 231-243. doi: 10.1037/a0025957.

Keren-Kolb, E.F. (2010). Stimulating Preservice Teachers' Beliefs About The Benefits Of Everyday Technology In Their Teaching. (Disertasi, The University of Michigan). Diterima dari http://search.proquest.com.

Kumara, A. (2011). [Program School WellBeing]. Tidak dipublikasikan.

Kramer, T. L., Vuppala, A., Lamps, C., Miller, T. L., \& Trush, C. R. (2006). The interface between mental health providers, families, and schools: parent and child attitudes about information-sharing. Journal of Child and Family Studies, 15, 4, 377-392. doi : 10.1007/s10826-006-9019-z.

Langeveld, J., Joa, I., Larsen, T. K., Rennan, J.A., Cosmovici, E., \& Johannessen, J. 
A. (2011). Teachers' awareness for psychotic symptoms in secondary school: the effects of an early detection programme and information campaign, Early Intervention in Psychiatry,5,115-121. doi:10.1111/j.1751-7893.2010.00248.x.

Loades, M. E., \& Mastroyannopoulou, K. (2010). Teachers' recognition of children's mental health problems. Child and Adolescent Mental Health, 15, 3, 150-156. doi: 10.1111/j.14753588.2009.00551.x.

Luxton, D.D., Russell, A.M., Bush, N.E., Mishkind, M.C., \& Reger, G.M. (2011). MHealth for mental health: integrating smartphone technology in behavioral healthcare, Professional Psychology: Research and Practice, 42, 6, 505-512. doi : 10.1037/a0024485.

Murray, C., \& Pianta, R. C. (2007). The importance of teacher-student relationships for adolescents with high incidence disabilities. Adolescent Mental Health, 46, 2, 105-112. Abstrak diterima dari: http://www.tandfonline.com.

Reavley, N.J., McCann, T.C., \& Jorm, A.F. (2012). Mental health literacy in higher education students, Early Intervention in Psychiatry, 6, 1,45-52. doi:10.1111/j.1751-7893.2011.00314.x.

Reigeluth, C.M., \& Chellman-arr, A.A. (2009). Instructional-Design Theories and Models Volume III. New York: Taylor and Francis, Publisher.

Russell, J.D., \& Johanningsmeier, K.A. (1981). Improving Competence Through Modular Instruction. Iowa : Kendall/Hunt Publishing Company.

Shadish, W. R., Cook, T. D., \& Campbell, D. T. (2002). Experimental and Quasi- experimental Designs for Generalized Causal Inference. Boston : Houghton Mifflin.

Vaz, S., Falkmer, M., Parsons, R., Passmore, A.E., Parkin, T. \& Falkmer., T. (2014). School belongingness and mental health functioning across the primary-secondary transition in a mainstream sample: multi-group cross-lagged analyses, PLOS ONE, 9, 6, 1-10. doi:10.1371/ journal. pone. 0099576.

Whitley, J., Smith, J.D. \& Vaillancourt., T. (2012). Promoting mental health literacy among educators: critical in school- based prevention and intervention, Canadian Journal of School Psychology, 28, 1, 56-70. doi : $10.1177 / 0829573512468852$.

World Health Organization (WHO). 2003. Caring for children and adolescents with mental disorders seting WHO directions. Diterima dari World Health Organization Diterima dari : http://www.who.int/. 